\title{
Assessing impacts of social-ecological diversity on resilience in a wetland coupled human and natural system
}

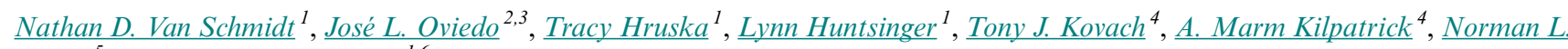
Miller $^{5}$ and Steven R. Beissinger ${ }^{1,6}$

\begin{abstract}
Theory posits that resilience of ecosystems increases when there is a diversity of agents (e.g., species) and linkages between them. If ecosystems are conceptualized as components of coupled human and natural systems, then a corollary would be that novel types of human-induced diversity may also foster resilience. We explored this hypothesis by studying how socially created diversity mediated the impact of a historically severe drought on a network of wetlands in the foothills of the California Sierra Nevada containing a metapopulation of the threatened California Black Rail (Laterallus jamaicensis coturniculus). We examined how (1) diversity in motivations for land ownership affected use of irrigation water and response to drought; (2) differences in natural and irrigated water sources affected wetland drying in response to drought; and (3) these processes affected the persistence of rails and the transmission risk of West Nile virus (WNV), an emerging infectious disease that threatens people and rails. Wetlands were mostly fed by inefficiencies and leaks from the irrigation system. Wetlands with both natural and irrigated water sources were larger, wetter, and likelier to persist through drought because these two sources showed response diversity by drying at different times. Wetlands with diverse water sources also provided the best habitat for the California Black Rail, and irrigation appeared responsible for its persistence through the drought. Irrigation increased WNV transmission risk by increasing the quantity, but not the quality, of wetland habitats for mosquitoes. The impacts of social diversity were more ambiguous, with redundancy prevalent. However, profit-motivated landowners provided wetlands more irrigation during nondrought conditions, whereas other landowner types were more likely to continue providing irrigation during drought. Our results highlight that conservation in social-ecological systems requires assessing not only the value of historic ecological diversity, but also how novel types of socially induced diversity may benefit ecosystems.
\end{abstract}

Key Words: Black Rail; California; coupled human and natural system; CHANS; functional diversity; irrigation; Laterallus jamaicensis coturniculus; metapopulation; rangeland; resilience; response diversity; wetland;

\section{INTRODUCTION}

Recognition of the central role humans now occupy in the biosphere has led to calls for the definition of a new geologic epoch, the Anthropocene (Crutzen 2002). In ecology, this has corresponded with interest in novel ecosystems (e.g., humancreated habitats or species assemblages), conservation within working landscapes, and moving from an equilibrium-based model of ecological dynamics to one that integrates complex interactions, change, and co-adaption with social systems (Corlett 2015, Folke et al. 2016). Such systems are generally referred to as coupled human and natural systems (CHANS), social-ecological systems (SES), or human-environment systems (Liu et al. 2007). Coupled human and natural systems are characterized by heterogeneity, cross-scale interactions, feedback loops, and dramatic shifts between multiple quasi-equilibrium states when certain thresholds are crossed, resulting in complex nonlinear dynamics that hamper predictions of system behavior (Costanza et al. 1993, Schlüter et al. 2012, Folke et al. 2016).

Resilience theory has come to dominate the CHANS literature as a way to promote sustainability by managing for resilience in the face of this uncertainty (Brown 2014, Folke et al. 2016, Allen et al. 2018). The interdisciplinary nature of resilience theory within CHANS has resulted in diverse theoretical contributions and frameworks (reviewed in Folke 2006 and Folke et al. 2016). Resilience has been defined in multiple ways (Quinlan et al. 2015,
Angeler and Allen 2016) with ongoing debate (c.f. Hodgson et al. 2015 and responses). "Ecological resilience" is the magnitude of disturbance a system can withstand and maintain critical relationships and functions (Quinlan et al. 2015). "Engineering resilience" focuses on stability, measured by resistance (how much the system changes in response to disturbance) and recovery (the speed with which a system returns to prior condition afterward; Holling 1996). In the CHANS literature, resilience is generally equated with the concept of ecological resilience but can be expanded to include social adaptability (e.g., learning; Quinlan et al. 2015, Angeler and Allen 2016). A consensus definition is emerging based on commonalities that broadly equates resilience as a system's capacity to persist or maintain function following disturbance, with stability an aspect of resilience that can be quantified as resistance and recovery (Hodgson et al. 2015, Quinlan et al. 2015, Angeler and Allen 2016, Ingrisch and Bahn 2018). Several mechanisms have been proposed for fostering resilience of CHANS including managing diversity, connectivity, slow variables, feedbacks, and creating social networks and institutions that emphasize co-adaptation, learning, broad participation, and polycentric governance (Biggs et al. 2015).

One foundational hypothesis of resilience theory posits that resilience increases when stability is created by the diversity of agents and the linkages between them (Holling 1996, Walker et al. 2006). Diversity of agents (e.g., species or stakeholders)

${ }^{1}$ Department of Environmental Science, Policy, and Management, University of California - Berkeley, ${ }^{2}$ Consejo Superior de Investigaciones Científicas (CSIC), Institute of Marine Sciences of Andalusia (ICMAN), ${ }^{3}$ Consejo Superior de Investigaciones Científicas (CSIC), Institute of Public Goods and Policies (IPP), ${ }^{4}$ Department of Ecology and Evolutionary Biology, University of California - Santa Cruz, ${ }^{5}$ Department of Geography, University of California - Berkeley, ${ }^{6}$ Museum of Vertebrate Zoology, University of California - Berkeley 
enhances system function if each plays a different role in the provisioning of services (functional diversity). Even when agents play the same role (functional redundancy), they can enhance resilience by responding differently to disturbance (response diversity; Elmqvist et al. 2003, Leslie and McCabe 2013) because diverse responses reduce the risk of losing functions if one agent type in the system fails (the portfolio effect; Hooper et al. 2005). Resilience theory arose in part from studies of how diversity in biological communities creates overall system resilience, even though individual system components (e.g., species populations) may be highly variable (Holling 1973, Folke 2006). However, research on functional and response diversity in other ecological and social systems is lacking (Walker et al. 2006, Leslie and McCabe 2013, Kotschy et al. 2015, Hruska et al. 2017). The application of resilience theory to CHANS has consequently been criticized as being inappropriately applied to fundamentally different systems as an overly theoretical metaphor without empirical validation (Olsson et al. 2006, Brown 2014, Kotschy et al. 2015, Angeler and Allen 2016) Quantitatively evaluating whether or not other kinds of ecological and social diversity promote function and resilience is necessary to establish the validity of the diversity-resilience hypothesis within a scientific theory of CHANS (Walker et al. 2006, Kotschy et al. 2015, Angeler and Allen 2016).

We examined the influence of functional and response diversity of natural and social agents on the dynamics and resilience of a network of irrigation and freshwater wetlands in California's rangelands to a historic drought (Fig. 1). Over $90 \%$ of California wetlands have been destroyed since 1850 , mostly in the Central Valley (Lemly et al. 2000). In the adjacent foothills of the Sierra Nevada, however, numerous small (typically $<1$ ha) wetlands have been created, mostly on private lands that are comprised of large and small ranches in open oak (Quercus spp.) savannah and seasonal grasslands, rice (Oryza sativa) farms, and exurban and suburban residences (Richmond et al. 2010). Landowners create wetlands by irrigating and dry them by draining or reducing irrigation. Water is provisioned to landowners chiefly by two regional irrigation districts, which are governed by locally elected officials and respond to regulations and requirements from other state agencies. The irrigation districts deliver surface water to landowners from reservoirs that are fed by snowmelt from the peaks of the Sierra Nevada; the region does not overlie any major groundwater aquifer, and wells generally produce water only for household use (Huntsinger et al. 2017). Small wetlands provide important ecosystem services disproportionate to their size (Blackwell and Pilgrim 2011, Palta et al. 2017), exemplified in this CHANS by providing habitat for the California Black Rail (Laterallus jamaicensis coturniculus; hereafter Black Rail), a threatened bird experiencing population declines (Van Schmidt et al. 2019). This population was only discovered in 1994, although genetic evidence suggests a historic presence of this secretive bird in the region (Girard et al. 2010). Black Rail density is greater in foothills wetlands than in the larger wetlands of the San Francisco Bay, the only other population in northern California (Girard et al. 2010). Unfortunately, foothills wetlands also provide ecosystem disservices as habitat for mosquitoes that carry West Nile virus (WNV), an emerging infectious disease that threatens people and rails. Rail metapopulation dynamics, and potentially WNV transmission risk, are affected by the number, size, and persistence of wetlands (Risk et al. 2011, Van Schmidt et al. 2019, Van Schmidt and Beissinger 2020). Our study included three years (2013-2015) of historically severe drought (Diffenbaugh et al. 2015), bookended by wetter years $(2012,2016)$.

Fig. 1. System flow diagram of the irrigation-wetlands coupled human and natural system in California's Sierra Nevada foothills. System components (boxes) are connected by key linkages. Top-down processes (climate and governance institutions) are at the top, which differentially affect two diverse classes of central agents: wetlands with two classes of diverse water sources (natural/irrigated), and landowners with six classes of diverse motivations for owning their land (right inset). Wetlands provide ecosystem services (provisioning of habitat for a threatened species, the California Black Rail, Laterallus jamaicensis coturniculus) and disservices (habitat for an emerging infectious disease).

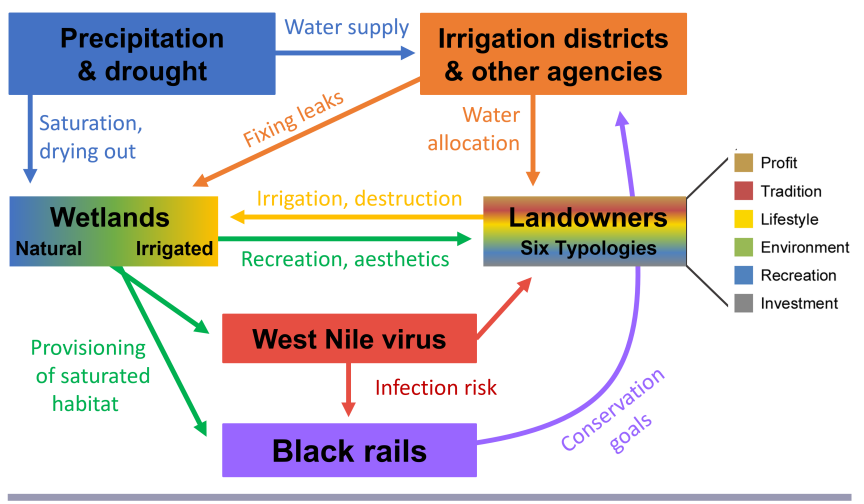

We tested whether functional and response diversity affected the CHANS' function and resilience to this historic drought. Our goal is not to conclusively demonstrate whether social and ecological diversity creates resilience in CHANS generally, which requires assessment across numerous components of many systems; rather, we seek to advocate for a research agenda that could address components of that question by (1) illustrating a framework for empirically quantifying different types of diversity in CHANS, and (2) assessing its utility for understanding the resilience dynamics of the Sierra foothills irrigation-wetlands CHANS. Following Quinlan et al.'s (2015) recommendations, we used a multi-scale, hybrid approach to quantify resilience by combining metrics with a holistic assessment of system dynamics. We combined remote sensing, field surveys of wetlands, and a mail survey sent to landowners to quantify two types of diversity, i.e., wetland hydrological diversity and landownership motivation diversity, and determine their influence on five aspects of this CHANS: wetland abundance, wetland saturation, landowner irrigation behavior, Black Rail dynamics, and WNV transmission risk. Because CHANS operate across multiple scales, we define resilience at three scales: (1) individual wetlands maintaining ecosystem functions; (2) landowners maintaining wetlands; and (3) system-wide maintenance of water and wetlands sufficient for persistence of Black Rails and landowner livelihoods. Quantifying overall resilience of an entire CHANS is likely impossible, necessitating the assessment of the specific resilience of focal system components to focal disturbances (Quinlan et al. 2015, Angeler and Allen 2016, Allen et al. 2018). We focused on 
two dimensions of resilience to drought: (1) water availability, because irrigation water shortages are an important concern of landowners (Huntsinger et al. 2017); and (2) the occupancy dynamics of rails because wetland habitat goals in central California focus on waterbirds and perennially saturated wetlands (Duffy and Kahara 2011), which are critical for the survival of Black Rails in the foothills (Van Schmidt et al. 2019). The Black Rail is a suitable focus for resilience because it is a wetland habitat specialist threatened at state and federal levels, making it useful as an indicator species.

\section{METHODS}

\section{Wetland sampling}

We mapped all emergent wetlands $>5 \times 5 \mathrm{~m}$ within our study area, i.e., California's Sierra Nevada foothills EPA zone III ecoregion (US Environmental Protection Agency 2013) in Yuba, Nevada, and southern Butte counties, by manually interpreting summer 2013 GeoEye-1 $0.4 \mathrm{~m}$ imagery in Google Earth 7.1.5 (Appendix 1). Each wetland's geomorphology was classified as slope (shallow hillside flow), pond fringe, fluvial, rice fringe, irrigation ditch, or waterfowl impoundment.

We combined historic imagery and field data to determine the water sources of 934 wetlands $(53 \%$ of 1760 total wetlands, including all wetlands on survey respondents' properties; Appendix 1). All statistical analyses included only wetlands whose water sources were known. We estimated the number and total area of the remaining 826 wetlands that were supported by each water source based on the sampled sites (Appendix 1).

To assess the effects of water source on wetland hydrology, we resurveyed $n=117$ wetlands for 14 periods: in the early wet season (January 8-27), late wet season (March 22-25), early dry season (May 17-June 20), and late dry season (July 15-August 15) from summer 2013-2016. At each visit, we estimated the percent wetness (areal percent of wetland saturated with water) using a map of aerial imagery. Not all wetlands could be sampled in all time periods because of access restrictions; we discarded any sites that were not visited $\geq 5$ times in both the dry and wet season, leaving $n=1343$ observations. We compared the frequency drying out ( $\leq 5 \%$ wetness) at least once during the drought between sites with only one versus two water sources using a $\chi^{2}$ test ( $R$ base package "stats"). We fit Tobit regressions (Tobin 1958) in the R package "censReg" (v 0.5.26) to estimate the expected percent wetness of wetlands during each period (Appendix 1, Table A1.1). We excluded the impoundments (large, intensively managed waterfowl hunting wetlands found only in the Central Valley) from this analysis because they had complex management cycles of water drawdowns, planting, and re-flooding. For reference, we present the prior 100 days' precipitation for the mean date of each sampling period, obtained from CIMIS weather station \#84 near the center of our study area.

\section{Social sampling}

In 2013-2014, we mailed a survey on land and water management, based on the Dillman Total Design method (Dillman et al. 2014), to a selection of regional landowners with properties $\geq 1.2$ ha stratified by property size (see Huntsinger et al. 2017 for the survey). We sent surveys to $n=862$ valid addresses, including 129 non-randomly selected landowners that were cooperators with our field research. There were $n=470$ surveys returned (a $55 \%$ response rate), including 64 from non-random landowners. From 2013-2016, we also conducted 51 interviews with landowners and irrigation district employees about water management, which helped inform survey design and interpret responses. Data collection protocols for human subjects were approved by Committee for the Protection of Human Subjects (UCB-IRB protocol \#2011-06-3324).

Social functional diversity can be conceptualized in CHANS as diversity of actor groups that perform different functions, and disparate livelihoods are expected to enhance CHANS' resilience by exhibiting response diversity to shocks to production (Walker et al. 2006, Kotschy et al. 2015, Grêt-Regamey et al. 2019). We used factor analysis to quantify social diversity by identifying six landowner typologies based on reported motivations for owning land, which has often been used to examine connections between motives and behavior (Ferranto et al. 2013, Sorice et al. 2014). We focused on diversity of motivations for owning land because this region is a epicenter of urban out-migration, with exurban development for retirees, commuters, recreational vacation homes, and others replacing local grazing economies over the past several decades (Walker et al. 2003, Huntsinger et al. 2017). Our survey asked respondents to score 20 reasons for owning land from 1 "not important at all" to 4 "very important." We identified landowner typologies from $n=354$ respondents who scored all the 20 reasons by performing a factor analysis, which finds linear relationships (factor loadings) between observed variables of interest (the reported reasons) and a smaller number of unobserved factors (the typologies). We assigned each landowner to the typology for which they had the highest standardized factor loadings and labeled each typology based on shared characteristics of the subset of the 20 reasons.

We subsequently used these typologies in statistical tests (Appendix 1) for differences among respondents in their number of water features (functional diversity) and responses to drought reported in the survey (response diversity; Table A1.2) using stated preference methods as per Johnston et al. (2017).

\section{Black Rail and West-Nile virus (WNV) sampling}

We surveyed 237 wetlands for occupancy of Black Rails up to three times each summer from 2012-2016 using established broadcast survey methods (for details see Richmond et al. 2010). We assessed the impact of water source diversity on the Black Rail metapopulation by fitting a multi-season occupancy model (MacKenzie et al. 2003) in Program PRESENCE v11.7 and assessing model fit with AIC (Appendix 1). Area and year were also included as occupancy covariates in the best model (Appendix 1, Table A1.3). We used AIC weights to calculate model-averaged estimates of occupancy in each year for an average wetland with each of the three water sources (Appendix 1, Table A1.4). We then used $95 \%$ confidence intervals calculated via the delta method to determine if there were significant differences in Black Rail occupancy throughout the drought for irrigated, natural, or both-source wetlands.

We trapped mosquitoes at 63 wetlands from June-October, 2012-2014 (4710 trap/nights) and estimated WNV prevalence (probability of a mosquito testing positive for WNV) with genetic testing (Appendix 1, Table A1.5). We estimated WNV transmission risk at each wetland as the mean abundance of WNV-infected Culex spp. (the main WNV vectors) per trap/night. 
We used ANCOVAs to test for effects of water source on WNV risk while controlling for wetland size (Appendix 1, Fig. A1.1).

\section{RESULTS AND DISCUSSION}

\section{Hydrological diversity}

We identified 1760 wetlands totaling 644.863 ha (Fig. 2) and quantified their hydrologic diversity based on water sources as natural-only ( $15 \%$ of sites), irrigation-only ( $62 \%)$, or both-source $(24 \%)$. Most irrigated wetlands were created by inefficiencies and benign neglect, with $74 \%$ fed by leaks from ditches or ponds, oversaturated pasture or rice, or runoff (Fig. 3a). Wetlands were generally small $($ median $=0.090$ ha, range: $<0.001-11.459$ ha $)$, but both-source wetlands were significantly larger (median $\pm \mathrm{SE}$ $=0.284 \pm 0.053 \mathrm{ha})$ than irrigation-only $(0.168 \pm 0.015 \mathrm{ha})$ and natural-only wetlands $(0.076 \pm 0.007$ ha; Kruskal-Wallis $n=934$, $\chi^{2}=62.98$, with post-hoc Nemenyi pairwise tests with all $p<0.01$ ). By increasing wetland size, irrigation also increased wetness; wetlands were $7.6 \%$ wetter on average with each 10 -fold increase in size, presumably because they were fed by larger water sources with greater inertia (Appendix 1, Table A1.1).

Fig. 2. Mapped water features in the Sierra Nevada foothills, clustered in irrigation district service areas (inset: study area location in California).

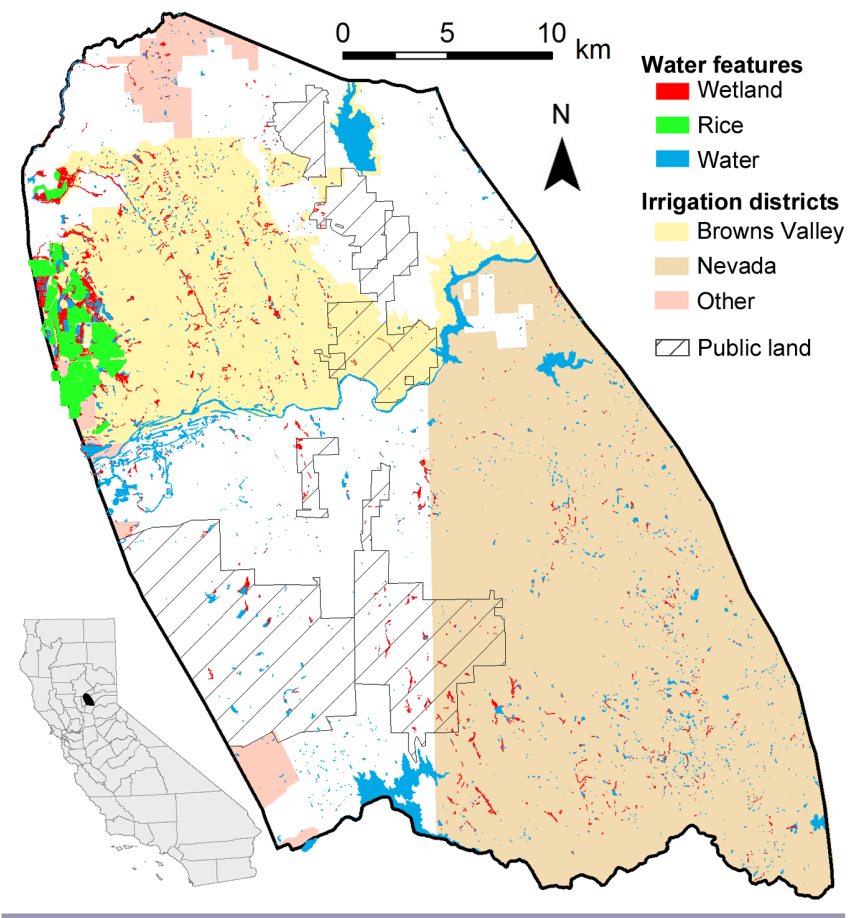

Wetlands with diverse water sources were more resistant to drought. Sites with both water sources dried out $(18.9 \pm 0.7 \% \mathrm{SE})$ significantly less frequently $\left(\chi^{2}=6.25, p=0.01\right)$ compared to sites with only one water source $(42.2 \pm 0.8 \%)$. The AIC model selection showed water source, but not wetland size, altered seasonal cycles of wetness during drought (Appendix 1, Table A1.1). In a non-drought year (2016), wetness varied little among sites with different water sources across seasons, whereas during the drought wetlands showed a diversity of drying cycles depending on hydrological sources, illustrating response diversity (Fig. 3b). Natural wetlands had seasonal drying with winter-wet water cycles: they stayed wet during California's rainy Mediterranean winter but dried in the summer dry season (and other periods of low rainfall) during the drought (Fig. 3b). Irrigation-only wetlands had less dramatic fluctuations but exhibited reverse-cycle seasonality: they were driest during the normally wet winter, when irrigation delivery generally ceased and ditches filled only from rain (Fig. 3b). Some irrigation-only wetlands also dried in the summer when irrigation ceased, possibly due to water conservation by landowners. Impoundments (a few large waterfowl hunting wetlands found only in the Central Valley) were excluded from this analysis because they had complex management cycles of water drawdowns, planting, and re-flooding.

Fig. 3. Characteristics of Sierra Nevada foothills wetland water source diversity. (a) Number and total area $( \pm 95 \% \mathrm{CI})$ of wetlands supported by water sources; rice, pasture, pond, and wetland describe landowner's intended irrigation use. Wetlands with multiple sources (e.g., all both-source wetlands) are counted in multiple bars. (b) Mean $( \pm$ SE) wetness (percent of surface saturated) of mean-sized wetlands over time ( $E=$ early and $\mathrm{L}=$ late in season) showed response diversity. The mean precipitation over the past 100 days for each period is shown for reference.

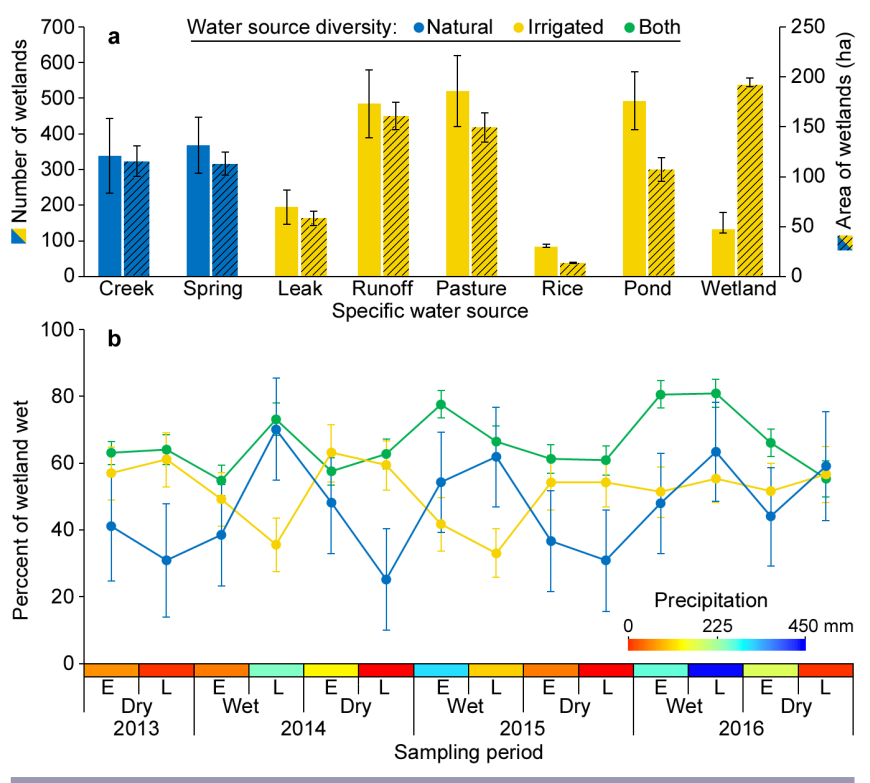

A diversity of water sources increased wetland resilience because sources responded differently to disturbance, exemplifying the portfolio effect. When irrigation water entered natural wetlands, it increased their resistance to drought by keeping them saturated because of differences in the timing of drying between the two water sources. Irrigation systems in California were engineered to alter the timing of water availability by storing precipitation in reservoirs to complement natural Mediterranean water cycles. The resulting reverse-cycle seasonality of irrigated wetlands mimics some historic Central Valley wetlands, which were fed by summer Sierra Nevada snowmelt. These have been disproportionately lost, creating a landscape with a higher 
Table 1. Landowner typologies in California's Sierra Nevada foothills as determined via weightings in a factorial analysis from a survey question on 20 reasons for land ownership $(n=354)$. These six typologies accounted for $64 \%$ of the variance in reasons for land ownership. Loadings are grouped and shown in bold by their landowner type.

\begin{tabular}{|c|c|c|c|c|c|c|c|}
\hline \multirow{2}{*}{$\begin{array}{l}\text { Landowner typology ( } \% \text { of } \\
\text { sample) }\end{array}$} & \multirow[t]{2}{*}{ Reason for land ownership } & \multicolumn{6}{|c|}{ Factor } \\
\hline & & 1 & 2 & 3 & 4 & 5 & 6 \\
\hline \multirow{5}{*}{$\begin{array}{l}\text { Lifestyle-motivated } \\
(16.9 \%)\end{array}$} & I want to escape or stay away from the city & 0.839 & 0.140 & 0.049 & 0.180 & 0.028 & 0.021 \\
\hline & I like to live in a smaller community & 0.839 & 0.158 & 0.045 & 0.189 & 0.020 & 0.030 \\
\hline & This is a healthy place to live & 0.631 & 0.421 & 0.147 & 0.128 & 0.120 & 0.054 \\
\hline & I like to live near natural beauty & 0.599 & 0.516 & -0.060 & 0.126 & -0.030 & 0.172 \\
\hline & To grow some of my own food & 0.539 & 0.272 & 0.410 & 0.078 & 0.045 & -0.016 \\
\hline \multirow{5}{*}{$\begin{array}{l}\text { Environment-motivated } \\
(15.3 \%)\end{array}$} & My land allows me to protect the environment & 0.267 & 0.773 & 0.058 & 0.129 & -0.024 & 0.190 \\
\hline & To preserve open space & 0.163 & 0.759 & 0.125 & 0.111 & 0.065 & -0.120 \\
\hline & I want to restore and manage this land & 0.126 & 0.672 & 0.388 & 0.191 & 0.073 & 0.022 \\
\hline & I enjoy improving this land & 0.253 & 0.620 & 0.416 & 0.055 & 0.050 & 0.016 \\
\hline & I enjoy seeing wildlife and/or birds & 0.518 & 0.565 & -0.119 & 0.053 & 0.186 & -0.044 \\
\hline \multirow{5}{*}{$\begin{array}{l}\text { Profit-motivated } \\
(15.8 \%)\end{array}$} & To raise cattle or sheep & 0.077 & 0.024 & 0.775 & 0.174 & -0.059 & -0.139 \\
\hline & My land is a source of income & -0.070 & 0.170 & 0.771 & 0.195 & -0.066 & 0.270 \\
\hline & Living on this land is a family business & 0.040 & 0.086 & 0.742 & 0.408 & -0.006 & 0.125 \\
\hline & To contribute to the local economy & 0.075 & 0.337 & 0.681 & 0.131 & 0.124 & 0.172 \\
\hline & To raise horses, ponies, donkeys, or mules & 0.375 & 0.039 & 0.429 & -0.257 & 0.202 & -0.021 \\
\hline \multirow{4}{*}{$\begin{array}{l}\text { Tradition-motivated } \\
(16.7 \%)\end{array}$} & I was born here or near here & 0.030 & -0.013 & 0.319 & 0.704 & 0.043 & -0.202 \\
\hline & A good place to raise my children & 0.220 & 0.066 & 0.175 & 0.678 & 0.089 & 0.012 \\
\hline & I want to pass this land to my heirs & 0.055 & 0.320 & 0.072 & 0.608 & 0.069 & 0.121 \\
\hline & I am closer to friends and family here & 0.363 & 0.191 & 0.139 & 0.581 & 0.102 & 0.094 \\
\hline \multirow{4}{*}{$\begin{array}{l}\text { Recreation-motivated } \\
(20.1 \%)\end{array}$} & For vacations & 0.025 & 0.082 & -0.008 & 0.062 & 0.760 & 0.078 \\
\hline & For recreation & 0.258 & 0.347 & -0.051 & 0.113 & 0.677 & -0.066 \\
\hline & To develop the land for future residential use & -0.220 & -0.183 & -0.025 & 0.034 & 0.554 & 0.406 \\
\hline & I enjoy hunting or fishing & 0.193 & -0.071 & 0.398 & 0.122 & 0.507 & -0.263 \\
\hline $\begin{array}{l}\text { Investment-motivated } \\
(15.3 \%)\end{array}$ & My land is a financial investment & 0.166 & 0.076 & 0.184 & 0.010 & 0.057 & 0.827 \\
\hline
\end{tabular}

proportion of winter-wet seasonal wetlands today than it had historically (Duffy and Kahara 2011). Thus, the transformation from a natural system to a CHANS has added human-created hydrological diversity by creating a quasi-novel ecosystem within the foothills that may be able to functionally mitigate the loss of natural hydrological diversity within the Central Valley. As in biological communities, adding variability to the system at one scale (individual water sources) increased system stability at a broader scale (individual wetlands; Holling 1996). Although individual wetlands may re-saturate after drying (analogous to studies of resilience in community ecology showing populations of individual species fluctuating), severe drought may disturb water availability sufficiently to permanently disrupt the CHANS' ability to maintain functions at the landscape scale (e.g., by extirpating species). Next, we quantify social diversity, and return later to examine if resistance to drying created by hydrological diversity affected the ability of wetlands to maintain function throughout the drought.

\section{Landowner diversity}

Landowners are responsible for wetlands in this region because $93 \%$ of wetlands occur on private land (Fig. 1). Our factor analysis quantified social diversity as six landowner typologies based on motivations for owning land (Table 1). These included profit- oriented agricultural production (profit, 16\% of respondents); family, tradition, and a sense of belonging to the land (tradition, $17 \%$ ); the lifestyle associated with rural life (lifestyle, $17 \%$ ); environmental and wildlife protection (environment, 15\%); vacation and recreational use (recreation, 20\%); and financial investment (investment, 15\%). There were no significant differences among typologies in property size (range: 1.2-3237.5 ha, $\left.F_{5,324}=0.97, p=0.43\right)$, household income $\left(F_{5,293}=1.44, p=\right.$ $0.21)$, or age $\left(F_{5,325}=0.57, p=0.72\right)$.

Functional redundancy was prevalent among landowner typologies. All typologies provided some irrigation, and many types exhibited similar water management (Fig. 4a, b). However, there was some functional diversity with different typologies having different types of wetlands. Compared to the other three typologies, in general, tradition-motivated landowners had more natural-fed wetlands, profit-motivated landowners had more irrigation-fed wetlands, and recreation-motivated landowners had more of both types of wetlands (Fig. 4a). There was substantial variation within typologies in the number of wetlands on their properties (Appendix 1, Fig. A1.2). Most landowners had no wetlands, and a few had many (excluding an outlier, wetlands per property ranged 0-6 for natural-fed wetlands and 0-32 for irrigation-fed wetlands). One outlier ranch had 138 
irrigated wetlands, most of which were waterfowl impoundments, which strongly influenced the number of irrigation-fed wetlands of recreation-motivated landowners. Although typical of hunting ranches in the Central Valley, recreation-motivated landowners elsewhere in the foothills had few irrigation-fed wetlands.

Overall, profit-motivated landowners had more irrigated water features (Fig. 4a) and were likelier to have created one recently (Fig. 4b). However, profit- and tradition-motivated landowners were likelier to fix leaks or reuse tailwater, actions that eliminate wetlands (Fig. 4b), possibly because these two typologies were more often ranchers or farmers $\left(F_{5,324}=15.65, p<0.001\right)$. All six typologies showed within-group variation in management and responses to drought (Fig. 4b, c), with many actions being taken by roughly half of the landowners and not taken by the other half.

\section{Impact of landowner diversity on responses to drought}

Redundancy in functional groups can help maintain system function if responses to disturbance differ (Hooper et al. 2005). We quantified social response diversity by examining how landowners indicated they would respond to water cutbacks, which can be mandated by irrigation districts. In response to the drought, irrigation districts banned runoff beyond property boundaries and dried wetlands by fixing irrigation ditch leaks. Irrigation districts either ceased winter water sales during the drought's peak, or permanently stopped them. Summer water cutbacks were nearly implemented, which reduced the amount of water delivered to landowners by $20-50 \%$ (Van Schmidt et al. 2019). Landowners can adjust how they use water or fix infrastructure but cannot readily adjust the amount of water they purchase from water districts and need to use their full allocation to retain it (Huntsinger et al. 2017). Landowners said they would respond to water cutbacks by reducing water to pastures $(31 \%$ of respondents), reusing runoff $(8 \%)$, and repairing leaks $(6 \%)$, which would affect up to $69 \%$ of the region's wetlands that were fed by these sources.

Landowner adaptation to hypothetical water cutbacks showed response diversity (Fig. 4c). Profit-motivated landowners were the most likely, and investment-motivated the least likely to take actions that would dry wetlands (i.e., reduce irrigation), such as repairing leaks, recycling runoff, or cutting irrigation to pasture (Appendix 1, Table A1.2). Although profit-motivated landowners had more water features (Fig. 4a), they were also more likely to state they would reduce irrigation should water be cut back (Fig. $4 c$ ). Other landowner types were likelier to maintain their water use under cutbacks, possibly because they purchased more water than they needed to maintain their water allocation, whereas profit-motivated landowners may be more fully utilizing their allocation (Huntsinger et al. 2017). Similarities between other typologies suggest that future studies could improve quantification of social diversity by grouping typologies that appeared functionally equivalent.

Our results suggest the CHANS benefits from a mix of economically motivated and non-economically motivated landowners. Under normal conditions with adequate rainfall, profit-motivated landowners irrigated more wetlands than other landowner types. Under disturbance conditions (i.e., drought and water cutbacks), however, profit-motivated landowners would reduce water to wetlands, whereas other landowner types would continue providing irrigation. This illustrates the value of response diversity even when one agent type performs best outside of disturbance conditions (Elmqvist et al. 2003). Thus, landowner diversity increases system function and resilience over time given oscillating environmental conditions, with some types performing better during drought and some during non-drought conditions.

Fig. 4. Functional (a, b) and response (c) diversity of Sierra Nevada foothills landowners based on landownership motivation typologies. Bars represent SE, and shared superscripts $(\mathrm{a}-\mathrm{d})$ represent groups without significant differences. (a) Expected number of different water-dependent features on a landowners' property $(n=351)$. (b) Proportion of landowners that took different water-management actions in the past five years $(\mathrm{n}=323,322,327$, and 333). (c) Proportion that responded to a hypothetical water cutback of $56.6 \%$ (mean value in survey) by taking adverse wetland-impacting (e.g., reducing irrigation) or landowner-impacting (e.g., reducing livestock stocking) actions $(\mathrm{n}=274)$.
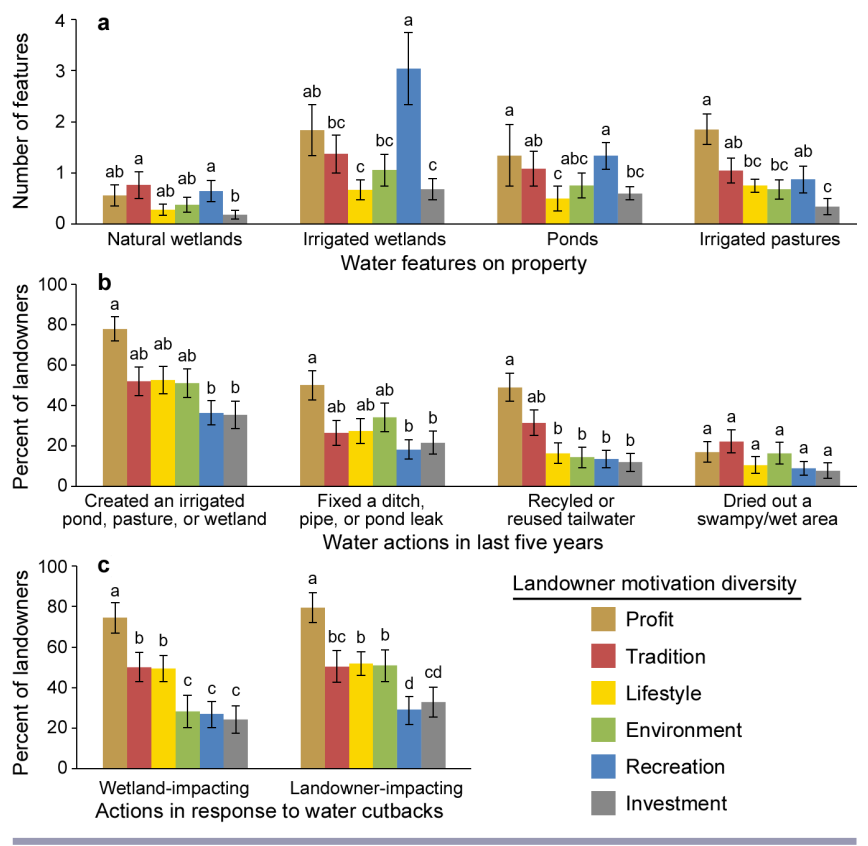

Landowner diversity can be undermined by severe water shortages. Profit-motivated landowners, who earn a higher percentage of their income from their land than other types $\left(F_{5,317}=6.736, p<0.001\right)$, were significantly more likely to suffer economic hardship, sell their land, or change livelihoods in response to water cutbacks (Fig. 4c; Appendix 1, Table A1.2), potentially resulting in property turnover, reallocation of water, and shifting land use. The social costs of cutbacks, thus, fall disproportionately on those providing more wetland ecosystem services. This jeopardizes long-term CHANS sustainability by increasing the risk of transformation to a system with less irrigation-intensive land uses (e.g., exurban development). Disturbance that overwhelmed resilience in one part of the CHANS (social land use) may produce cascading effects in other parts (e.g., wetland function and resilience).

Our findings add to other studies that have found evidence that social diversity can increase resilience. Heterogeneity in 
endowments of social groups (Baland and Platteau 1996) and overlapping governance structures (Folke et al. 2005, Ostrom 2009) have been empirically demonstrated to increase resilience. Leslie and McCabe (2013) and Grêt-Regamey et al. (2019) found pastoralists in range systems showed response diversity that increased resilience. In addition to response diversity, social diversity in problem-solving approaches can facilitate collective learning and adaptability, fostering resilience (Bendor and Page 2019). However, diversity can hinder adaptability when cultural differences increase inter-group conflicts (Kotschy et al. 2015, Page 2015).

\section{Impact of hydrological diversity on rails and WNV}

Irrigation increased both the quantity and quality of wetland habitat for California Black Rails. Natural-only wetlands had significantly lower rail occupancy than both-source wetlands in all years and irrigation-only wetlands during the drought (Fig. 5a). This effect was driven by two mechanisms. First, irrigation increased wetland size, and larger wetlands were more likely to be occupied (Appendix 1, Table A1.3). Second, water source was an important predictor of occupancy even after accounting for wetland size, indicating that water source diversity increased habitat quality (Appendix 1, Table A1.4). Several very large natural-only wetlands had dramatic seasonal drying and were unoccupied by Black Rails during this study. By the drought's end, no Black Rails were detected in natural-only wetlands.

Fig. 5. Impacts of Sierra Nevada foothills wetlands' hydrologic diversity on maintenance of ecosystem function during drought. (a) Mean ( $\pm 95 \% \mathrm{CI})$ probability of occupancy by California Black Rails (Laterallus jamaicensis coturniculus) for a median-sized wetland of each water source. (b) West Nile virus (WNV) -infected Culex mosquito abundance increased with wetland size $\left(\mathrm{r}^{2}=0.064, \mathrm{p}=0.045\right)$.

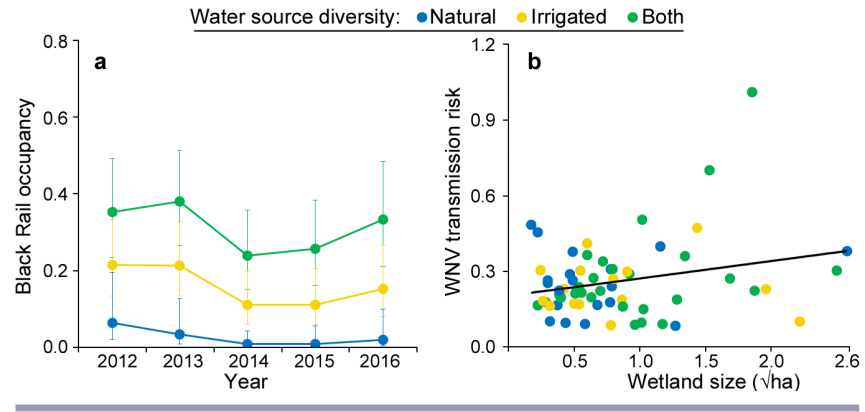

Irrigation increased WNV transmission risk by increasing the quantity, but not the quality, of wetland habitats for mosquitoes. Transmission risk increased with wetland size ( $p=0.045$; Fig. 5b) because mosquito abundance increased, while WNV prevalence was invariant (Appendix 1, Fig. A1.1). After controlling for wetland size, water source had no effect on transmission risk $\left(F_{2,59}=0.30, p=0.76\right)$, indicating that the increased persistence of both-source wetlands did not affect WNV dynamics.

Foothills irrigation development has created both services and disservices by expanding the amount of wetland habitat. The metrics we studied show irrigated wetlands offered more services (habitat provisioning) with fewer disservices (WNV risk) per hectare than natural wetlands. Wetlands with diverse water sources provided the best habitat for the threatened Black Rail during normal and drought conditions, demonstrating increased function and resilience. Genetic analyses suggest a presence of Black Rails in inland northern California before the addition of irrigation water (Girard et al. 2010), though their exact historic distribution is unknown. Regardless, this threatened bird now relies on irrigation: metapopulation viability analyses found that if landowners took their stated actions in response to water cutbacks during a severe drought, especially the reduction of pasture irrigation, it would risk regional extirpation of the Black Rail (Van Schmidt et al. 2019).

The benefits of hydrological diversity likely extend to some other species and functions. Small agricultural wetlands support wetland-dependent and even some upland species. Perennial and reverse-cycle wetlands in California have increased invertebrate diversity and abundance, providing important food sources for wildlife (de Szalay et al. 2003). Reverse-cycle wetlands are now among the rarest in the Central Valley, resulting in overcrowding of breeding waterbirds that is exacerbated by water shortages and drought (Duffy and Kahara 2011). Perennial wetlands also create important habitat for migratory birds because spring drying renders wetlands unsuitable for migrating birds (Duffy and Kahara 2011). Reverse-cycle irrigated wetlands provide water quality-related ecosystem services, like their natural counterparts (O'Geen et al. 2007). Although our results highlight the value of water source diversity within wetlands, maintaining a diversity of water source combinations at the landscape scale is also advisable: summer-wet, reverse-cycle, and non-seasonal wetlands support overlapping but complementary sets of species and functions (Duffy and Kahara 2011, Lunde and Resh 2012).

\section{Implications for water governance}

California is a globally important region for both agricultural production and wetland bird habitat (Duffy and Kahara 2011), and the state is under intense pressure to conserve water from the looming threat of droughts of greater frequency and intensity due to climate change (Diffenbaugh et al. 2015, Christian-Smith et al. 2015). Irrigation districts and the state have responded to drought by encouraging water conservation and optimizing irrigation use, which may foster social system resilience if the conserved water is not subsequently allocated to other users. However, such attempts to engineer CHANS stability can lead to unintended consequences (Holling 1996, Folke 2006).

Our research suggests the Sierra foothills irrigation-wetlands CHANS is vulnerable to this kind of top-down regulation, with few feedbacks to foster adaptation (e.g., incentives for landowners to preserve accidental wetlands). Most landowners valued wetland ecosystem services: $70.0 \%$ agreed that "I like wetlands because they attract wildlife." However, there is little institutional recognition of the importance of these wetlands. The California Department of Fish and Wildlife provides financial support to landowners for maintaining perennial water to intentional wetlands in the Central Valley (Duffy and Kahara 2011), but these programs do not extend to the "waste" water wetlands in the foothills. A complex set of physical and policy constraints leave irrigation districts few options to conserve water except by reducing the "waste water" that facilitates ecosystem resilience. Irrigation districts are incentivized to reduce leaks and runoff because the conserved water can be sold off-district for higher 
prices (Huntsinger et al. 2017), actions which two interviewees reported eliminated wetlands with rails in our study. Districts are not required to monitor for species before eliminating anthropogenic wetlands.

Resilience theory argues for shifting from policies intended to control and optimize exploitation of a system assumed to be stable to managing for the capacity of a system to cope with, adapt to, and shape change (Folke et al. 2016). Allowing for "waste" water may provide this CHANS the capacity to cope in the face of climate change but will require recognizing trade-offs between water conservation and ecosystem services within a policy framework. Water conservation policies could be balanced by including language that protects valued ecosystem services and recognizes the importance of irrigation for wetlands. Wetlands could be integrated into the water conveyance system; an interviewee with a leak-dependent wetland had worked with their irrigation district to do so. The infiltrated irrigation water from surface water reservoirs at upper elevations flows downhill through the fractured rock hydrology of this region and is likely reused downhill as it re-emerges in springs, creeks, or wells (Huntsinger et al. 2017). Intentional application of conjunctive use strategies coupling flood irrigation with groundwater recharge (i.e., Flood-MAR) is gaining traction within major agricultural groundwater basins in California (Langridge and Van Schmidt 2020), but it is only informally considered within the fractured rock systems like the foothills. Finally, water cutbacks could be applied in multiple tiers, targeting low-value uses first (e.g., lawns). Deferring cutbacks for irrigators engaged in commercial agriculture, like profit-oriented landowners, would increase the resilience of social diversity in this CHANS, the ecosystem functions fostered by it, and regional food production.

\section{CONCLUSIONS}

Water's central role in the biosphere and the tight co-evolution of human activities and water systems make it a potential unifying focus for studying and managing for resilience in the Anthropocene (Boltz et al. 2019). The transformation of the Sierra Nevada foothills into a hydrologically coupled human and natural system increased the resilience of water availability and the local wetland network's provisioning of rail habitat by adding social-ecological variability. Hydrological diversity in the foothills CHANS reflected functional diversity, redundancy, and response diversity - cornerstones upon which resilience theory developed (Holling 1973). Wetlands fed by diverse water sources had increased function and were more resistant to drying during the drought, which was crucial in maintaining the regional persistence of a threatened bird that otherwise may have faced extirpation. Similar dynamics likely occur in other regions in which seepage and runoff from irrigation are key water sources for wetlands (c. f. Sueltenfuss et al. 2013, Fernald et al. 2015, Palta et al. 2017). However, hybrid assessments of wetlands/rivers with water infrastructure represent only $10 \%$ of the water resilience literature, with most studies focused solely on infrastructure and engineering resilience (Rodina 2019). Although modifications to natural hydrology often have negative impacts on ecosystems (Gordon et al. 2008), where CHANS have already co-adapted to novel configurations, it will be critical to account for how diverse anthropogenic hydrological processes create resilient landscapes.

Our factor analysis method was able to quantify social diversity, but found fewer clear patterns than ecological diversity, illustrating the difficulty of quantifying diversity in social actors (Kotschy et al. 2015). Households and farms in working landscapes are heterogeneous, and the diversity of motivations and goals could be key to understanding land management decisions (c.f. Howley 2013, Ferranto et al. 2013, Sorice et al. 2014, Kumer and Štrumbelj 2017, Grêt-Regamey et al. 2019). In our study, the four non-economic typologies exhibited equivalent functions and responses to drought, and only profit-motivated landowners differed strongly in their irrigation behavior. However, they were not as resistant to disturbance as other landowner types, which otherwise offered fewer ecosystem services. Thus, social diversity increased function during both normal and disturbance conditions, creating a system of water provisioning to ecosystems that was more resilient to fluxes in water availability.

Some have argued that resilience in CHANS has become a metaphor without empirical validation (Olsson et al. 2006, Brown 2014). Although not conclusive, our findings add evidence that social and ecological process diversity contributes to resilience via the same mechanisms as biodiversity.

Responses to this article can be read online at: https://www.ecologyandsociety.org/issues/responses. php/12223

\section{Acknowledgments:}

We thank the field technicians, landowners, Jerry Tecklin, and Sierra Nevada Foothill Research and Extension Center for making this research possible. We thank the National Science Foundation (DEB-1051342, CNH-1115069), the Spanish Ministry of Culture and Education's Salvador de Madariaga program (PRX16/00452), and the Sierra Foothills Audubon Society for funding.

\section{Data Availability:}

The wetland, rail, and West Nile virus data that support the findings of this study are openly available in Dryad at https:lldoi. org/10.6078/D1970G. Partial social and geospatial data are available from the corresponding author, NVS, upon request (excluding some information that would make respondents identifiable).

\section{LITERATURE CITED}

Allen, C. R., H. E. Birge, D. G. Angeler, C. A. (T.) Arnold, B. C. Chaffin, D. A. DeCaro, A. S. Garmestani, and L. Gunderson. 2018. Quantifying uncertainty and trade-offs in resilience assessments. Ecology and Society 23(1):3. https://doi.org/10.5751/ ES-09920-230103

Angeler, D. G., and C. R. Allen. 2016. Quantifying resilience. Journal of Applied Ecology 53(3):617-624. https://doi. org/10.1111/1365-2664.12649

Baland, J.-M., and J.-P. Platteau. 1996. Halting degradation of natural resources: is there a role for rural communities? Food and Agriculture Organization of the United Nations, Rome, Italy. [online] URL: http://www.fao.org/3/x5316e/x5316e00.htm 
Bendor, J., and S. E. Page. 2019. Optimal team composition for tool-based problem solving. Journal of Economics and Management Strategy 28(4):734-764. https://doi.org/10.1111/ jems. 12295

Biggs, R., M. Schlüter, and M. L. Schoon, editors. 2015. Principles for building resilience: sustaining ecosystem services in socialecological systems. Cambridge University Press, Cambridge, UK. https://doi.org/10.1017/CBO9781316014240

Blackwell, M. S. A., and E. S. Pilgrim. 2011. Ecosystem services delivered by small-scale wetlands. Hydrological Sciences Journal 56(8):1467-1484. https://doi.org/10.1080/02626667.2011.630317

Boltz, F., N. LeRoy Poff, C. Folke, N. Kete, C. M. Brown, S. St. George Freeman, J. H. Matthews, A. Martinez, and J. Rockström. 2019. Water is a master variable: solving for resilience in the modern era. Water Security 8:100048. https://doi.org/10.1016/j. wasec. 2019.100048

Brown, K. 2014. Global environmental change I: a social turn for resilience? Progress in Human Geography 38(1):107-117. https:// doi.org/10.1177/0309132513498837

Christian-Smith, J., M. C. Levy, and P. H. Gleick. 2015. Maladaptation to drought: a case report from California, USA. Sustainability Science 10(3):491-501. https://doi.org/10.1007/ s11625-014-0269-1

Corlett, R. T. 2015. The Anthropocene concept in ecology and conservation. Trends in Ecology and Evolution 30(1):36-41. https:// doi.org/10.1016/j.tree.2014.10.007

Costanza, R., L. Wainger, C. Folke, and K.-G. Mäler. 1993. Modeling complex ecological economic systems. BioScience 43 (8):545-555. https://doi.org/10.2307/1311949

Crutzen, P. J. 2002. Geology of mankind. Nature 415(6867):23. https://doi.org/10.1038/415023a

de Szalay, F. A., L. C. Carroll, J. A. Beam, and V. H. Resh. 2003. Temporal overlap of nesting duck and aquatic invertebrate abundances in the Grasslands Ecological Area, California, USA. Wetlands 23(4):739-749. https://doi.org/10.1672/0277-5212(2003) 023[0739:TOONDA] 2.0.CO;2

Diffenbaugh, N. S., D. L. Swain, and D. Touma. 2015. Anthropogenic warming has increased drought risk in California. Proceedings of the National Academy of Sciences 112 (13):3931-3936. https://doi.org/10.1073/pnas.1422385112

Dillman, D. A., J. D. Smyth, and L. M. Christian. 2014. Internet, phone, mail, and mixed-mode surveys: the tailored design method. John Wiley and Sons, Hoboken, New Jersey, USA.

Duffy, W. G., and S. N. Kahara. 2011. Wetland ecosystem services in California's Central Valley and implications for the Wetland Reserve Program. Ecological Applications 21(sp1):S128-S134. https://doi.org/10.1890/09-1338.1

Elmqvist, T., C. Folke, M. Nyström, G. Peterson, J. Bengtsson, B. Walker, and J. Norberg. 2003. Response diversity, ecosystem change, and resilience. Frontiers in Ecology and the Environment 1(9):488-494. https://doi.org/10.1890/1540-9295(2003)001[0488: RDECAR $2.0 . \mathrm{CO} ; 2$
Fernald, A., S. Guldan, K. Boykin, A. Cibils, M. Gonzales, B. Hurd, S. Lopez, C. Ochoa, M. Ortiz, J. Rivera, S. Rodriguez, and C. Steele. 2015. Linked hydrologic and social systems that support resilience of traditional irrigation communities. Hydrology and Earth System Sciences 19(1):293-307. https://doi.org/10.5194/ hess-19-293-2015

Ferranto, S., L. Huntsinger, C. Getz, M. Lahiff, W. Stewart, G. Nakamura, and M. Kelly. 2013. Management without borders? A survey of landowner practices and attitudes toward crossboundary cooperation. Society and Natural Resources 26 (9):1082-1100. https://doi.org/10.1080/08941920.2013.779343

Folke, C. 2006. Resilience: the emergence of a perspective for social-ecological systems analyses. Global Environmental Change 16(3):253-267. https://doi.org/10.1016/j.gloenvcha.2006.04.002

Folke, C., R. Biggs, A. V. Norström, B. Reyers, and J. Rockström. 2016. Social-ecological resilience and biosphere-based sustainability science. Ecology and Society 21(3):41. https://doi.org/10.5751/ ES-08748-210341

Folke, C., T. Hahn, P. Olsson, and J. Norberg. 2005. Adaptive governance of social-ecological systems. Annual Review of Environment and Resources 30(1):441-473. https://doi.org/10.1146/ annurev.energy.30.050504.144511

Girard, P., J. Y. Takekawa, and S. R. Beissinger. 2010. Uncloaking a cryptic, threatened rail with molecular markers: origins, connectivity and demography of a recently-discovered population. Conservation Genetics 11(6):2409-2418. https://doi. org/10.1007/s10592-010-0126-4

Gordon, L. J., G. D. Peterson, and E. M. Bennett. 2008. Agricultural modifications of hydrological flows create ecological surprises. Trends in Ecology and Evolution 23(4):211-219. https:// doi.org/10.1016/j.tree.2007.11.011

Grêt-Regamey, A., S. H. Huber, and R. Huber. 2019. Actors' diversity and the resilience of social-ecological systems to global change. Nature Sustainability 2(4):290-297. https://doi. org/10.1038/s41893-019-0236-Z

Hodgson, D., J. L. McDonald, and D. J. Hosken. 2015. What do you mean, 'resilient'? Trends in Ecology and Evolution 30 (9):503-506. https://doi.org/10.1016/j.tree.2015.06.010

Holling, C. S. 1973. Resilience and stability of ecological systems. Annual Review of Ecology and Systematics 4:1-23. https://doi. org/10.1146/annurev.es.04.110173.000245

Holling, C. S. 1996. Engineering resilience versus ecological resilience. Pages 31-43 in P. Schulze, editor. Engineering within ecological constraints. National Academy of Engineering, Washington, D.C., USA.

Hooper, D. U., F. S. Chapin, III, J. J. Ewel, A. Hector, P. Inchausti, S. Lavorel, J. H. Lawton, D. M. Lodge, M. Loreau, S. Naeem, B. Schmid, H. Setälä, A. J. Symstad, J. Vandermeer, and D. A. Wardle. 2005. Effects of biodiversity on ecosystem functioning: a consensus of current knowledge. Ecological Monographs 75 (1):3-35. https://doi.org/10.1890/04-0922

Howley, P. 2013. Examining farm forest owners' forest management in Ireland: the role of economic, lifestyle and multifunctional ownership objectives. Journal of Environmental Management 123:105-112. https://doi.org/10.1016/j.jenvman.2013.03.013 
Hruska, T., L. Huntsinger, M. Brunson, W. Li, N. Marshall, J. L. Oviedo, and H. Whitcomb. 2017. Rangelands as social-ecological systems. Pages 263-302 in D. D. Briske, editor. Rangeland systems. Springer, Berlin, Germany. https://doi.org/10.1007/978-3-319-46709-2_8

Huntsinger, L., T. V. Hruska, J. L. Oviedo, M. W. K. Shapero, G. A. Nader, R. S. Ingram, and S. R. Beissinger. 2017. Save water or save wildlife? Water use and conservation in the Central Sierran foothill oak woodlands of California, USA. Ecology and Society 22(2):12. https://doi.org/10.5751/ES-09217-220212

Ingrisch, J., and M. Bahn. 2018. Towards a comparable quantification of resilience. Trends in Ecology and Evolution 33 (4):251-259. https://doi.org/10.1016/j.tree.2018.01.013

Johnston, R. J., K. J. Boyle, W. Adamowicz, J. Bennett, R. Brouwer, T. A. Cameron, W. M. Hanemann, N. Hanley, M. Ryan, R. Scarpa, R. Tourangeau, and C. A. Vossler. 2017. Contemporary guidance for stated preference studies. Journal of the Association of Environmental and Resource Economists 4 (2):319-405. https://doi.org/10.1086/691697

Kotschy, K., R. Biggs, T. Daw, C. Folke, and P. C. West. 2015. Principle 1 - maintain diversity and redundancy. Pages 50-79 in M. Schlüter, M. L. Schoon, and R. Biggs, editors. Principles for building resilience: sustaining ecosystem services in socialecological systems. Cambridge University Press, Cambridge, UK. https://doi.org/10.1017/cbo9781316014240.004

Kumer, P., and E. Štrumbelj. 2017. Clustering-based typology and analysis of private small-scale forest owners in Slovenia. Forest Policy and Economics 80:116-124. https://doi.org/10.1016/j. forpol.2017.03.014

Langridge, R., and N. D. Van Schmidt. 2020. Groundwater and drought resilience in the SGMA era. Society and Natural Resources 33(12):1530-1541. https://doi.org/10.1080/08941920.2$\underline{020.1801923}$

Lemly, A. D., R. T. Kingsford, and J. R. Thompson. 2000. Irrigated agriculture and wildlife conservation: conflict on a global scale. Environmental Management 25(5):485-512. https:// doi.org/10.1007/s002679910039

Leslie, P., and J. T. McCabe. 2013. Response diversity and resilience in social-ecological systems. Current Anthropology 54 (2):114-143. https://doi.org/10.1086/669563

Liu, J., T. Dietz, S. R. Carpenter, M. Alberti, C. Folke, E. Moran, A. N. Pell, P. Deadman, T. Kratz, J. Lubchenco, E. Ostrom, Z. Ouyang, W. Provencher, C. L. Redman, S. H. Schneider, and W. W. Taylor. 2007. Complexity of coupled human and natural systems. Science 317(5844):1513-1516. https://doi.org/10.1126/ science. 1144004

Lunde, K. B., and V. H. Resh. 2012. Development and validation of a macroinvertebrate index of biotic integrity (IBI) for assessing urban impacts to Northern California freshwater wetlands. Environmental Monitoring and Assessment 184(6):3653-3674. https://doi.org/10.1007/s10661-011-2214-4

MacKenzie, D. I., J. D. Nichols, J. E. Hines, M. G. Knutson, and A. B. Franklin. 2003. Estimating site occupancy, colonization, and local extinction when a species is detected imperfectly. Ecology 84(8):2200-2207. https://doi.org/10.1890/02-3090
O’Geen, A. T., J. J. Maynard, and R. A. Dahlgren. 2007. Efficacy of constructed wetlands to mitigate non-point source pollution from irrigation tailwaters in the San Joaquin Valley, California, USA. Water Science and Technology 55(3):55-61. https://doi. org/10.2166/wst.2007.072

Olsson, P., L. H. Gunderson, S. R. Carpenter, P. Ryan, L. Lebel, C. Folke, and C. S. Holling. 2006. Shooting the rapids: navigating transitions to adaptive governance of social-ecological systems. Ecology and Society 11(1):18. https://doi.org/10.5751/ES-01595-110118

Ostrom, E. 2009. Understanding institutional diversity. Princeton University Press, Princeton, New Jersey, USA.

Page, S. E. 2015. What sociologists should know about complexity. Annual Review of Sociology 41(1):21-41. https://doi. org/10.1146/annurev-soc-073014-112230

Palta, M. M., N. B. Grimm, and P. M. Groffman. 2017. "Accidental" urban wetlands: ecosystem functions in unexpected places. Frontiers in Ecology and the Environment 15(5):248-256. https://doi.org/10.1002/fee.1494

Quinlan, A. E., M. Berbés-Blázquez, L. J. Haider, and G. D. Peterson. 2015. Measuring and assessing resilience: broadening understanding through multiple disciplinary perspectives. Journal of Applied Ecology 53(3):677-687. https://doi.org/10.1111/1365-2664.12550

Richmond, O. M. W., S. K. Chen, B. B. Risk, J. Tecklin, and S. Beissinger. 2010. California Black Rails depend on irrigation-fed wetlands in the Sierra Nevada foothills. California Agriculture 64 (2):85-93. https://doi.org/10.3733/ca.v064n02p85

Risk, B. B., P. de Valpine, and S. R. Beissinger. 2011. A robustdesign formulation of the incidence function model of metapopulation dynamics applied to two species of rails. Ecology 92(2):462-474. https://doi.org/10.1890/09-2402.1

Rodina, L. 2019. Defining "water resilience": debates, concepts, approaches, and gaps. WIREs Water 6(2):e1334. https://doi. org/10.1002/wat2.1334

Schlüter, M., R. R. J. Mcallister, R. Arlinghaus, N. Bunnefeld, K. Eisenack, F. Hölker, E. J. Milner-Gulland, B. Müller, E. Nicholson, M. Quaas, and M. Stöven. 2012. New horizons for managing the environment: a review of coupled social-ecological systems modeling. Natural Resource Modeling 25(1):219-272. https://doi.org/10.1111/j.1939-7445.2011.00108.x

Sorice, M. G., U. P. Kreuter, B. P. Wilcox, and W. E. Fox, III. 2014. Changing landowners, changing ecosystem? Landownership motivations as drivers of land management practices. Journal of Environmental Management 133:144-152. https://doi. org/10.1016/j.jenvman.2013.11.029

Sueltenfuss, J. P., D. J. Cooper, R. L. Knight, and R. M. Waskom. 2013. The creation and maintenance of wetland ecosystems from irrigation canal and reservoir seepage in a semi-arid landscape. Wetlands 33(5):799-810. https://doi.org/10.1007/s13157-013-0437-6

Tobin, J. 1958. Estimation of relationships for limited dependent variables. Econometrica 26(1):24-36. https://doi.org/10.2307/1907382 
US Environmental Protection Agency (EPA). 2013. Level III ecoregions of the conterminous United States. Map. U.S. EPA Office of Research and Development (ORD) - National Health and Environmental Effects Research Laboratory (NHEERL), Corvallis, Oregon, USA.

Van Schmidt, N. D., and S. R. Beissinger. 2020. The rescue effect and inference from isolation-extinction relationships. Ecology Letters 23(4):598-606. https://doi.org/10.1111/ele.13460

Van Schmidt, N. D., T. Kovach, A. M. Kilpatrick, J. L. Oviedo, L. Huntsinger, T. Hruska, N. L. Miller, and S. R. Beissinger. 2019. Integrating social and ecological data to model metapopulation dynamics in coupled human and natural systems. Ecology 100(6): e02711. https://doi.org/10.1002/ecy.2711

Walker, B. H., L. H. Gunderson, A. P. Kinzig, C. Folke, S. R. Carpenter, and L. Schultz. 2006. A handful of heuristics and some propositions for understanding resilience in social-ecological systems. Ecology and Society 11(1):13. https://doi.org/10.5751/ ES-01530-110113

Walker, P., S. Marvin, and L. Fortmann. 2003. Landscape changes in Nevada County reflect social and ecological transitions. California Agriculture 57(4):115-121. https://doi.org/10.3733/ca. $\underline{\mathrm{v} 057 \mathrm{n} 04 \mathrm{p} 115}$ 
Appendix 1: Modeling methods and additional results

\section{Wetland diversity modeling}

We mapped all emergent wetlands $>5 \times 5 \mathrm{~m}$ within our study area. This minimum mapping unit included virtually all wetland patches in the study area and was less than the size of the smallest breeding home range we measured for Black Rails (0.16 ha; S.R. Beissinger, unpublished data). Areas covered by hydrophytes (Typha spp., Scirpus spp., Juncus effusus, Leersia oryzoides, or various sedges) were considered wetland. We included hydrophytes that dried seasonally; if green vegetation was present along the wetland-upland transition zone, we buffered $5 \mathrm{~m}$ around it. Open water and rice were excluded. If imagery was ambiguous, we used Google Earth imagery from adjacent years to help distinguish if a wetland was present. Patches were considered separate wetlands if they were $>100 \mathrm{~m}$ from another patch of wetland, had different water sources, or were different management units (e.g., separate ponds).

We classified the water sources of the 623 wetlands on the properties of survey respondents (see Social sampling) using historical (1947-2015) aerial photographs of the landscape under different irrigation regimes to determine if natural springs or creeks existed before the addition of irrigation water. We also assessed all 222 wetlands on public lands and the remaining 16 rice fringe, 10 irrigation ditch, and 4 waterfowl impoundment wetlands on nonrespondent properties to give us a comprehensive sample of these groups. We were able to gain property access to conduct field surveys of 271 wetlands ( 59 of which were newly assessed wetlands opportunistically added), supplementing our aerial interpretation with visual site inspections and interviews with landowners about water sources.

To determine the total number and area of wetlands supported by each water source, we estimated the number and total area of the remaining 826 (47\% of all wetlands) privately owned fringe, slope, and fluvial wetlands that were supported by each water source. We first calculated the percent and areal percent of each of the three types of wetlands supported by each water source in our $n=934$ known-source wetlands. We then multiplied these percentages by the total number and area of unknown-source wetlands in each of these categories, and then added them to the known-source wetlands in those categories. For example, for the number of spring-fed slope geomorphology wetlands (using only data from private lands):

$\#$ spring -slope wetlands $=$ \# known spring slope + \# unknown slope $\times \frac{\# \text { known spring slope }}{\# \text { known slope }}$

Confidence intervals were calculated based on the original proportions and then multiplied by the total number or area of unknown-source wetlands.

We fit Tobit regressions (Tobin 1958) in the R package censReg (v0.5.26) to estimate the expected percent wetness of wetlands during each period. We used Tobit regression censored at 0 and 1 and with a random effect for site, which was suitable for percent wetness data because wetlands could experience additional drying below $0 \%$ percent wetness (i.e., changing firm mud to cracked dry ground), while large inflows of water could cause flooding beyond $100 \%$ of the polygon saturated. We analyzed a model set that included water source (a factor; natural-only, irrigation-only, or both-source), wetland area (ln hectares), and interactions between these and 
Appendix 1: Modeling methods and additional results

each sampling period. For wetlands whose size varied annually (i.e., experienced changes in extent of hydrophyte cover) we used the maximum area (measured from aerial imagery) and corrected wetness estimates by multiplying the field-estimated percent wetness times the percent of the maximum area filled by the current area. We selected the best model via Akaike information criterion (AIC; Table A1.1). Impoundments (large, intensively managed waterfowl hunting wetlands found only in the Central Valley) were excluded from this analysis because they had complex management cycles of water drawdowns, planting, and re-flooding.

\section{Social diversity modeling}

Principal components analysis has been used to identify landowner types based on land management actions in Ireland and Switzerland (Howley 2013, Grêt-Regamey et al. 2019), and Kumer and Štrumbelj (2017) employed cluster analysis to identify different goals and values for small-scale private forest owners in Slovenia. We took the approach of Ferranto et al. (2013) and Sorice et al. (2014), who used factor analysis to identify landowner typologies in California and Texas rangeland based on ownership motivations, respectively.

We used our wetland mapping to count the number of natural-fed wetlands, irrigation-fed wetlands, ponds, and irrigated pastures on respondents' parcels in 2013. We fit generalized linear models in R (v3.2.2) to test for differences in number of each of these water features. Distributions were skewed (Figure A1.2), so we tested Poisson, quasi-Poisson (base package stats), negative binomial (package $M A S S$ v7.3), hurdle negative binomial, and zero-inflated negative binomial models using (package $p s c l$ v1.5). Standard errors, observed vs. expected zero counts, and maximum likelihood were used holistically to assess fit, and we determined a negative binomial fit best.

To assess response diversity we used survey-based methods that provided respondents different stimuli in hypothetical situations to which they are asked to state their preferences and hypothetical decision. Stated preferences and conjoint analysis are two popular forms of surveybased methods with a well-established literature (Louviere et al. 2010, Johnston et al. 2017). These methods estimate a function where the probability of a specific hypothetical action or answer depends on one or several stimuli variables. When a stimulus is a specific dollar amount to be paid that is randomly varied among the sample of respondents according to a pre-specified vector of values, an associated willingness to pay measure can be estimated. In our study, we adapted these methods by using potential water allocation cutbacks during drought as the stimuli and different potential land-based actions to be taken by the landowners as the response. As some of the presented actions are not mutually exclusive, we were able to generate a probability model for each action separately. While the social dimension of our study is based on hypotheticals, it was the best available approach for understanding potential landowner actions when facing further water cutbacks. An alternative would have been to monitor land-use decisions in response to actual stimuli, but that would require a long time horizon, and we would not have control over the variables. Moreover, it is extremely challenging to monitor individual landowner actions within their properties at a landscape scale. 
Our survey included a question asking landowners how they would respond to hypothetical water cutbacks of 20,50 , or $100 \%$ (each landowner was randomly asked about one of these cutback levels). We used logistic regressions (NLOGIT v5.0) to analyze landowner responses to hypothetical water cutbacks by modeling the probability of a landowner taking adaptive actions that would negatively impact wetlands (e.g., reducing irrigation) or a landowner's livelihood (e.g., ceasing livestock rearing; see Table A1.2 for details). Response options to cutbacks that we presented in the survey were based on preliminary interviews. A write-in option was available but rarely used, indicating the provided choices captured the likely responses. Aside from typology, we included cutback amount, property size, and household income as variables. The final model is in Table A1.2. Because of the inclusion of these nonrandom responses, we report results on the respondents rather than the population; the proportion of landowners in each typology was similar between respondents and full population estimates (3.5\% mean absolute difference).

\section{Black Rail occupancy modeling}

We assessed the impact of water source diversity on the Black Rail metapopulation by fitting a multi-season occupancy model (MacKenzie et al. 2003) using Program PRESENCE v11.7 (Appendix 1). Potential covariates for probabilities of initial occupancy $(\psi)$, colonization $(\gamma)$, and extinction $(\varepsilon)$ we assessed were water source and three nuisance variables: area (natural log of hectares +1 ), isolation (an autoregressive $7 \mathrm{~km}$ buffer radius measure obtained from Hall et al. (2018), and year (a set of dummy variables; not included on initial occupancy). Detection ( $p$ ) only included year as a covariate. Continuous variables were standardized.

We implemented our occupancy modeling in two phases. First, to reduce the size of the model set we carried out a backwards model selection exercise for the three nuisance covariates. Water source was included in all models and AIC was used to assess model fit. The lowest AIC model included area as a covariate on $\psi, \gamma$, and $\varepsilon$, and year as a covariate on $\gamma$ (Table A1.3). Unlike previous studies in this system (Risk et al. 2011), there was only weak support ( $>3 \Delta$ AIC) for isolation influencing occupancy dynamics during this time period, possibly due to very low colonization rates during the drought. In the second phase we retained the nuisance variables from the best model and then ran a full model set of all possible water source combinations (Table A1.4). For both phases, covariates were included for initial occupancy if they were included for either colonization or extinction.

Finally, we used AIC weights of the water source model set to calculate model-averaged estimates of occupancy in each year for an average wetland with each of the three water sources. Because area of wetlands significantly differed among water sources, we used the median area in our black rail sample for each category: 0.076 ha for natural-only, 0.168 ha for irrigation-only, and 0.284 for both-source. We used $95 \%$ confidence intervals calculated via the delta method to assess significant differences. 
Appendix 1: Modeling methods and additional results

\section{WNV modeling}

From June-October 2012-2014, we trapped mosquitoes at 63 wetlands (size range 0.03-6.7 ha) for 1,201 total site visits. We sampled 50 wetlands for one year and 13 wetlands in all three years. We visited each wetland weekly and set up four Center for Disease Control traps baited with dry ice, distributed along the wetland edge at $\geq 100 \mathrm{~m}$ intervals to capture spatial variation in mosquito densities; at some very small wetlands, shorter intervals needed to be used. The same trap locations were used at each visit. All mosquitoes caught were identified to species using morphological keys (Darsie and Ward 1981). For each wetland, we estimated the abundance of the main mosquito WNV vectors as the mean number of Culex mosquitoes caught per trap/night (from 4,710 trap/nights).

To estimate WNV prevalence at each wetland, we first extracted RNA using RNeasy kits (Qiagen) followed by RT-PCR (Qiagen) on 2,551 pools of 1-50 Culex mosquitoes (Kauffman et al. 2003). We included at least one positive and negative control alongside each set of 40 reactions and all WNV-positive pools were run twice to confirm presence of WNV. In the few cases where a pool tested positive and then negative, we conducted a third test to determine WNV status. We then used bias-reduced generalized linear models using package brglm in R (v3.13) with a binomial distribution and an offset for mosquito pool size to estimate WNV prevalence using the presence/absence of WNV in 2,539 pools (mean 14.6 mosquitoes/pool). The full model included site, date, date ${ }^{2}$, year, and interaction terms as predictors. The model with the lowest AIC (Table A1.5) was used to estimate WNV prevalence, the mean probability of a Culex testing positive for WNV at each wetland across all dates. Finally, we estimated WNV transmission risk at each wetland as the mean abundance of WNV-infected Culex mosquitoes (mean Culex abundance $\times$ mean Culex WNV prevalence).

We used analysis of covariance to test for effects of water source on the abundance of all mosquitoes, abundance of Culex, WNV prevalence, and WNV transmission risk, while controlling for the effect of wetland size (Fig. A1.1). We used a square root transformation on wetland size to equalize leverage and on all metrics involving mosquito abundance to maintain adequate homogeneity of variance.

\section{References}

Darsie, R. F., and R. A. Ward. 1981. Identification and geographical distribution of the mosquitoes of North America, north of Mexico. Mosquito Systematics Supplement 1:1313.

Ferranto, S., L. Huntsinger, C. Getz, M. Lahiff, W. Stewart, G. Nakamura, and M. Kelly. 2013. Management without borders? A survey of landowner practices and attitudes toward cross-boundary cooperation. Society \& Natural Resources 26(9):1082-1100.

Grêt-Regamey, A., S. H. Huber, and R. Huber. 2019. Actors' diversity and the resilience of social-ecological systems to global change. Nature Sustainability 2(4):290-297. 
Appendix 1: Modeling methods and additional results

Hall, L. A., N. D. Van Schmidt, and S. R. Beissinger. 2018. Validating dispersal distances inferred from autoregressive occupancy models with genetic parentage assignments. Journal of Animal Ecology 87(3):691-702.

Howley, P. 2013. Examining farm forest owners' forest management in Ireland: The role of economic, lifestyle and multifunctional ownership objectives. Journal of Environmental Management 123:105-112.

Johnston, R. J., K. J. Boyle, W. Adamowicz, J. Bennett, R. Brouwer, T. A. Cameron, W. M. Hanemann, N. Hanley, M. Ryan, R. Scarpa, R. Tourangeau, and C. A. Vossler. 2017. Contemporary guidance for stated preference studies. Journal of the Association of Environmental and Resource Economists 4(2):319-405.

Kauffman, E. B., S. A. Jones, A. P. Dupuis, K. A. Ngo, K. A. Bernard, and L. D. Kramer. 2003. Virus detection protocols for west nile virus in vertebrate and mosquito specimens. Journal of Clinical Microbiology 41(8):3661-3667.

Kumer, P., and E. Štrumbelj. 2017. Clustering-based typology and analysis of private small-scale forest owners in Slovenia. Forest Policy and Economics 80:116-124.

Louviere, J. J., T. N. Flynn, and R. T. Carson. 2010. Discrete choice experiments are not conjoint analysis. Journal of Choice Modelling 3(3):57-72.

MacKenzie, D. I., J. D. Nichols, J. E. Hines, M. G. Knutson, and A. B. Franklin. 2003. Estimating site occupancy, colonization, and local extinction when a species is detected imperfectly. Ecology 84(8):2200-2207.

Risk, B. B., P. de Valpine, and S. R. Beissinger. 2011. A robust-design formulation of the incidence function model of metapopulation dynamics applied to two species of rails. Ecology 92(2):462-474.

Sorice, M. G., U. P. Kreuter, B. P. Wilcox, and W. E. Fox. 2014. Changing landowners, changing ecosystem? Land-ownership motivations as drivers of land management practices. Journal of Environmental Management 133:144-152.

Tobin, J. 1958. Estimation of relationships for limited dependent variables. Econometrica 26(1):24-36. 
Table A1.1. AIC table for Tobit (censored 0-1) models of wetness of Sierra Nevada foothills wetlands, 2013-2016, with a random effect for site. Period is a factor representing 12 sampling time periods, source is a factor representing three water sources (natural-only, irrigation-only, both-source) and area was natural log of wetland size in hectares.

\begin{tabular}{|c|c|c|c|c|}
\hline Model & AIC weight & $\Delta \mathrm{AIC}$ & AIC & $\mathrm{k}$ \\
\hline Period + source + sourcexperiod + area & 0.766 & 0.00 & 294.95 & 45 \\
\hline Period + source + sourcexperiod + area + area $\times$ period & 0.226 & 2.44 & 297.39 & 58 \\
\hline $\begin{array}{l}\text { Period }+ \text { source }+ \text { sourcexperiod }+ \text { area }+ \text { area } \times \text { period } \\
+ \text { sourcexarea }\end{array}$ & 0.005 & 10.26 & 305.21 & 60 \\
\hline Period + source + sourcexperiod + area + source $\times$ area & 0.004 & 10.47 & 305.42 & 47 \\
\hline $\begin{array}{l}\text { Period }+ \text { source }+ \text { sourcexperiod }+ \text { area }+ \text { area } \times \text { period } \\
+ \text { sourcexarea }+ \text { source } \times \text { area } \times \text { period }\end{array}$ & 0.000 & 25.63 & 320.58 & 86 \\
\hline Period + source + sourcexperiod & 0.000 & 52.98 & 347.93 & 44 \\
\hline Period + source + area + area $\times$ period + source $\times$ area & 0.000 & 61.65 & 356.60 & 32 \\
\hline Period + source + area + source $\times$ area & 0.000 & 66.92 & 361.88 & 34 \\
\hline Period + area + area $\times$ period & 0.000 & 74.11 & 369.06 & 30 \\
\hline Period + source + area + area $\times$ period & 0.000 & 90.50 & 385.45 & 19 \\
\hline Period + source + area & 0.000 & 93.50 & 388.45 & 21 \\
\hline Period + area & 0.000 & 101.49 & 396.44 & 17 \\
\hline Period + source & 0.000 & 139.21 & 434.16 & 18 \\
\hline Period & 0.000 & 164.36 & 459.31 & 16 \\
\hline
\end{tabular}


Appendix 1: Modeling methods and additional results

Table A1.2. Logistic regression coefficients (SE in parentheses) for Sierra Nevada foothills landowners' management actions in response to a hypothetical water availability cutback (either 20,50 , or $100 \%$; included as a continuous covariate) from all sources $(n=274)$. Asterisks $(*, * *$, $* * *)$ denote significance at the 10,5 , and $1 \%$ levels.

\begin{tabular}{llc}
\hline \hline Class & Wetland-impacting action ${ }^{\mathrm{a}}$ & Landowner-impacting action $^{\mathrm{b}}$ \\
\hline Intercept (investment-motivated) & $-1.1503^{* * *}(0.3732)$ & $-0.7160^{* *}(0.3385)$ \\
Profit-motivated & $2.2133^{* * *}(0.5032)$ & $2.0702 * * *(0.4937)$ \\
Tradition-motivated & $1.1467 * *(0.4924)$ & $0.7343(0.4615)$ \\
Lifestyle-motivated & $1.1178^{* *}(0.4763)$ & $0.7979 *(0.4474)$ \\
Environment-motivated & $0.2088(0.5165)$ & $0.7538(0.4597)$ \\
Recreation-motivated & $0.1437(0.4857)$ & $-0.1673(0.4572)$ \\
Water cutback $(\%)$ & $-0.1934(0.2690)$ & $0.2178(0.2590)$ \\
Household income $(\$ 2013)$ & $0.7315^{* * *}(0.2781)$ & $0.1301(0.2662)$ \\
Property size (acres) & $0.6822^{*}(0.3935)$ & $0.6105 *(0.3666)$
\end{tabular}

a Includes responses "Repair leaks in ditches, pipes, dams and/or ponds", "Recycle and/or reuse tailwater, irrigation or pond runoff", "Stop or use less water to irrigate pasture(s)" and "Reduce area of irrigated pasture".

${ }^{\mathrm{b}}$ Includes responses "Stop or reduce growing crops or gardening", "Sell livestock or reduce stocking rate", "Find other grazing land", "Sell some or all the land", "Purchase water from outside (non-district) sources" and "Change to a different land use. 
Table A1.3. Backwards stepwise AIC model selection table for a multi-season occupancy model for the Sierra Nevada foothills metapopulation of the California Black Rail (Laterallus jamaicensis coturniculus), 2012-2016. Starting with the full model (step 0), nuisance parameters (area, isolation, and year) were removed one at a time, and the lowest AIC was selected. The process was repeated until we found the lowest AIC (bold). Water source (natural, irrigated, or both; irrigated left out) was in all models.

\begin{tabular}{|c|c|c|c|c|c|}
\hline Step & Model & AIC weight & $\Delta \mathrm{AIC}$ & AIC & $\mathrm{k}$ \\
\hline 3 & $\Psi($ area, nat $\neq$, both), $\gamma($ year, area, nat, both), $\varepsilon($ area, nat, both $), p()$. & 0.2199 & 1.32 & 1450.17 & 16 \\
\hline 3 & $\Psi($ area, nat, both $), \gamma($ year, nat, both $), \varepsilon($ year, area, nat, both $), p()$. & 0.0643 & 3.78 & 1452.63 & 18 \\
\hline 3 & $\Psi($ area, nat, both $), \gamma($ area, nat, both $), \varepsilon($ year, area, nat, both $), \mathrm{p}(.) \dagger$ & 0.0104 & 7.43 & 1456.28 & 16 \\
\hline 2 & $\Psi($ area, nat, both $), \gamma($ year, area, nat, both $), \varepsilon($ year, area, nat, both $), p()$. & 0.4255 & $\mathbf{0 . 0 0}$ & 1448.85 & 19 \\
\hline 2 & $\Psi($ area, iso $\S$, nat, both $), \gamma($ year, area, iso, nat, both), $\varepsilon($ area, nat, both $), \mathrm{p}()$. & 0.064 & 3.79 & 1452.64 & 18 \\
\hline 2 & $\Psi($ area, iso, nat, both $), \gamma($ year, iso, nat, both), $\varepsilon($ year, area, nat, both $), p()$. & 0.0404 & 4.71 & 1453.56 & 20 \\
\hline 2 & $\Psi($ area, iso, nat, both $), \gamma($ area, iso, nat, both $), \varepsilon($ year, area, nat, both $), \mathrm{p}(.) \dagger$ & 0.0033 & 9.73 & 1458.58 & 18 \\
\hline 2 & $\Psi($ area, nat, both $), \gamma($ year, area, nat, both), $\varepsilon($ year, nat, both $), p()$. & 0.0000 & 29.91 & 1478.76 & 18 \\
\hline 1 & $\Psi($ area, iso, nat, both $), \gamma($ year, area, iso, nat, both), $\varepsilon($ year, area, nat, both), $\mathrm{p}()$. & 0.1171 & 2.58 & 1451.43 & 21 \\
\hline 1 & $\Psi($ area, nat, both $), \gamma($ year, area, nat, both), $\varepsilon($ year, area, nat, both $), p($ year $)$ & 0.0355 & 4.97 & 1453.82 & 23 \\
\hline 1 & $\Psi($ area, iso, nat, both), $\gamma($ year, area, iso, nat, both), $\varepsilon$ (area, nat, both), p(year) & 0.0077 & 8.03 & 1456.88 & 22 \\
\hline 1 & $\Psi($ area, iso, nat, both $), \gamma($ year, iso, nat, both), $\varepsilon$ (year, area, nat, both), $\mathrm{p}($ year $)$ & 0.0026 & 10.18 & 1459.03 & 24 \\
\hline 1 & $\Psi($ area, iso, nat, both $), \gamma($ area, iso, nat, both $), \varepsilon($ year, area, nat, both $), p($ year $) \dagger$ & 0.0002 & 15.33 & 1464.18 & 22 \\
\hline 1 & $\Psi($ area, iso, nat, both $), \gamma($ year, area, iso, nat, both), $\varepsilon($ year, nat, both $), p()$. & 0.0000 & 32.02 & 1480.87 & 20 \\
\hline 1 & $\Psi($ area, iso, nat, both), $\gamma($ year, area, iso, nat, both), $\varepsilon$ (year, nat, both), $\mathrm{p}($ year $)$ & 0.0000 & 34.44 & 1483.29 & 24 \\
\hline 0 & $\Psi($ area, iso, nat, both), $\gamma($ year, area, iso, nat, both), $\varepsilon$ (year, area, nat, both), p(year) & 0.0091 & 7.68 & 1456.53 & 25 \\
\hline Null & $\Psi(),. \gamma(),. \varepsilon(),. \mathrm{p}()$. & 0.0000 & 111.10 & 1559.95 & 4 \\
\hline
\end{tabular}

$\dagger$ Models that did not include a year effect on $\gamma$ could not estimate SE for natural because the beta estimate was infinitely negative

+ Natural

$\S$ Isolation 
Table A1.4. AIC table for multi-season occupancy models for the Sierra Nevada foothills metapopulation of the California Black Rail (Laterallus jamaicensis coturniculus), 2012-2016, to assess the impact of water source on occupancy. All models except for the "true null model" have area as a covariate for $\Psi, \gamma$, and $\varepsilon$, and year dummy variables as covariates for $\gamma$ and $\varepsilon$.

\begin{tabular}{|c|c|c|c|c|}
\hline Model & AIC weight & $\Delta \mathrm{AIC}$ & AIC & $\mathrm{k}$ \\
\hline$\Psi$ (natural, both), $\gamma($ natural, both), $\varepsilon$ (natural), $\mathrm{p}()$. & 0.3017 & 0.00 & 1447.35 & 18 \\
\hline$\Psi($ natural, both $), \gamma($ natural, both $), \varepsilon(),. \mathrm{p}()$. & 0.2235 & 0.60 & 1447.95 & 17 \\
\hline$\Psi($ natural, both $), \gamma($ natural, both $), \varepsilon($ natural, both $), p()$. & 0.1425 & 1.50 & 1448.85 & 19 \\
\hline$\Psi($ natural, both $), \gamma($ natural, both $), \varepsilon($ both $), p()$. & 0.0895 & 2.43 & 1449.78 & 18 \\
\hline$\Psi($ natural $), \gamma($ natural $), \varepsilon$ (natural), $\mathrm{p}()$. & 0.0667 & 3.02 & 1450.37 & 16 \\
\hline$\Psi$ (natural, both), $\gamma($ both $), \varepsilon$ (natural), $p()$. & 0.0496 & 3.61 & 1450.96 & 17 \\
\hline$\Psi($ natural $), \gamma($ natural $), \varepsilon(),. \mathrm{p}()$. & 0.0479 & 3.68 & 1451.03 & 15 \\
\hline$\Psi$ (natural, both), $\gamma($ both $), \varepsilon($ natural, both), $\mathrm{p}()$. & 0.0245 & 5.02 & 1452.37 & 18 \\
\hline$\Psi($ natural, both), $\gamma($ natural $), \varepsilon($ natural, both), $\mathrm{p}()$. & 0.0236 & 5.10 & 1452.45 & 18 \\
\hline$\Psi($ natural, both $), \gamma($ natural $), \varepsilon($ both $), p()$. & 0.0156 & 5.93 & 1453.28 & 17 \\
\hline$\Psi($ both $), \gamma($ both $), \varepsilon(),. \mathrm{p}()$. & 0.0098 & 6.86 & 1454.21 & 15 \\
\hline$\Psi($ both $), \gamma($ both $), \varepsilon($ both $), p()$. & 0.0039 & 8.72 & 1456.07 & 16 \\
\hline$\Psi($ natural $), \gamma(),. \varepsilon$ (natural), $\mathrm{p}()$. & 0.0008 & 11.81 & 1459.16 & 15 \\
\hline$\Psi($ natural, both $), \gamma(),. \varepsilon($ natural, both $), \mathrm{p}()$. & 0.0003 & 13.84 & 1461.19 & 17 \\
\hline$\Psi($ both $), \gamma(),. \varepsilon($ both $), p()$. & 0.0000 & 17.78 & 1465.13 & 15 \\
\hline$\Psi(),. \gamma(),. \varepsilon(),. p()$. & 0.0000 & 17.84 & 1465.19 & 13 \\
\hline True null model & 0.0000 & 112.60 & 1559.95 & 4 \\
\hline
\end{tabular}


Appendix 1: Modeling methods and additional results

Table A1.5. AIC table for bias-reduced general linear models (binomial distribution and offsets accounting for differences in number of mosquitoes per pool) used to estimate West Nile virus prevalence at wetlands $(n=63)$ in the Sierra Nevada foothills.

\begin{tabular}{lllll}
\hline \hline Model & AIC weight & $\Delta$ AIC & AIC & $\mathrm{k}$ \\
\hline site + date + date ${ }^{2}+$ year & 0.501 & 0.0 & 1561.30 & 67 \\
site + date + date ${ }^{2}$ & 0.394 & 0.5 & 1561.78 & 65 \\
site & 0.075 & 3.8 & 1565.09 & 63 \\
site + date & 0.030 & 5.7 & 1566.95 & 64 \\
sitexdate + date2 + year & 0.000 & 76.9 & 1638.23 & 129 \\
sitexdate + sitexdate ${ }^{2}+$ year & 0.000 & 183.1 & 1744.44 & 191 \\
sitexdate + sitexdate ${ }^{2}+$ site* year & 0.000 & 207.4 & 1768.69 & 215 \\
\hline
\end{tabular}


Appendix 1: Modeling methods and additional results

Figure A1.1. Relationships between wetland size and three elements of West Nile virus transmission risk in the Sierra Nevada foothills. (a) Mean number of all mosquitoes caught per trap/night increased with wetland size (abundanc $e^{0.5}=2.94+1.74 *$ size $e^{0.5}, r^{2}=0.27, p<0.001$ ). (b) Mean number of Culex mosquitoes caught per trap/night increased with wetland size (abundance $e^{0.5}=2.31+0.81 \times$ size $\left.e^{0.5}, r^{2}=0.12, p=0.005\right)$. (c) There was no relationship between mean West Nile virus prevalence in Culex and wetland size $(p=0.671)$.
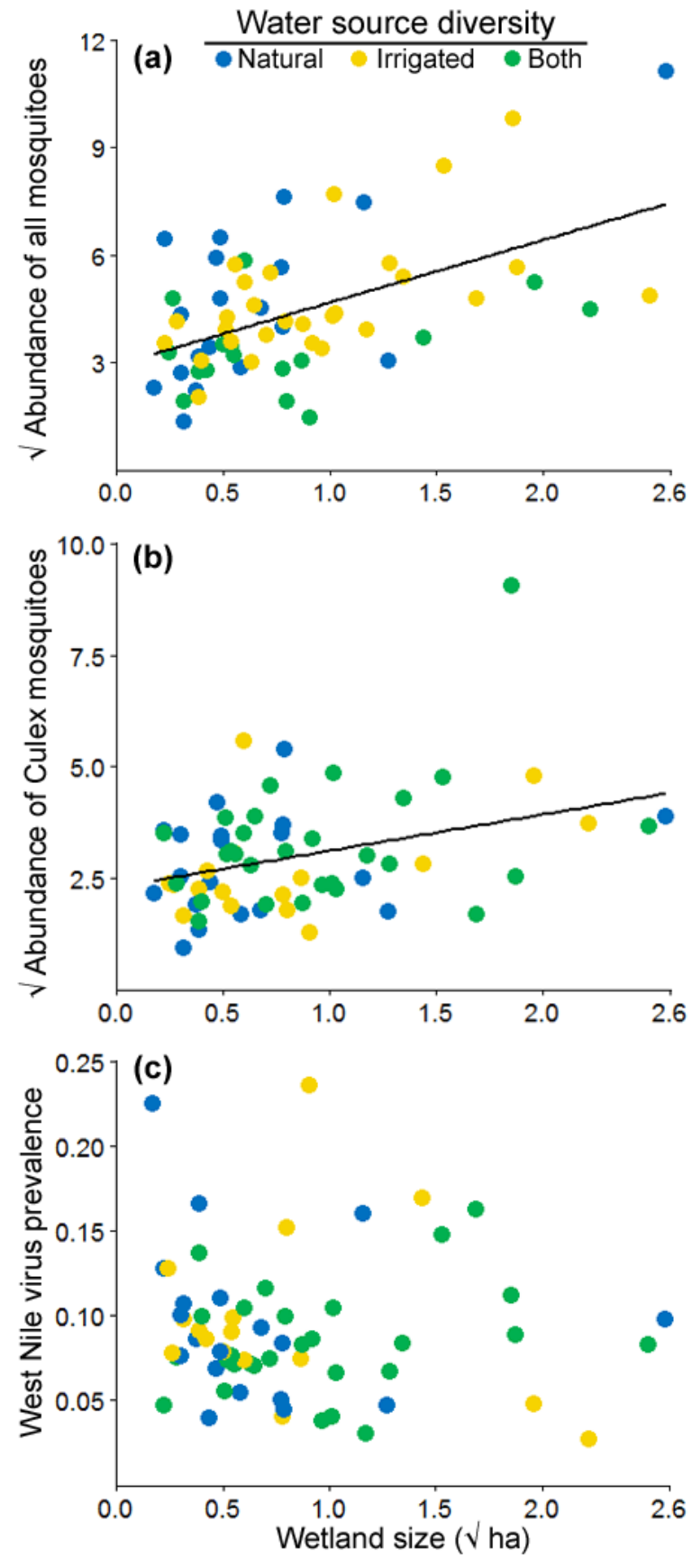
Appendix 1: Modeling methods and additional results

Figure A1.2. Histograms (15 bins) of the number of (a) natural-fed wetlands and (b) irrigationfed wetlands on $n=351$ landowner respondents' properties. One outlier recreation-motivated landowner with 138 irrigation-fed wetlands was excluded from panel $b$.
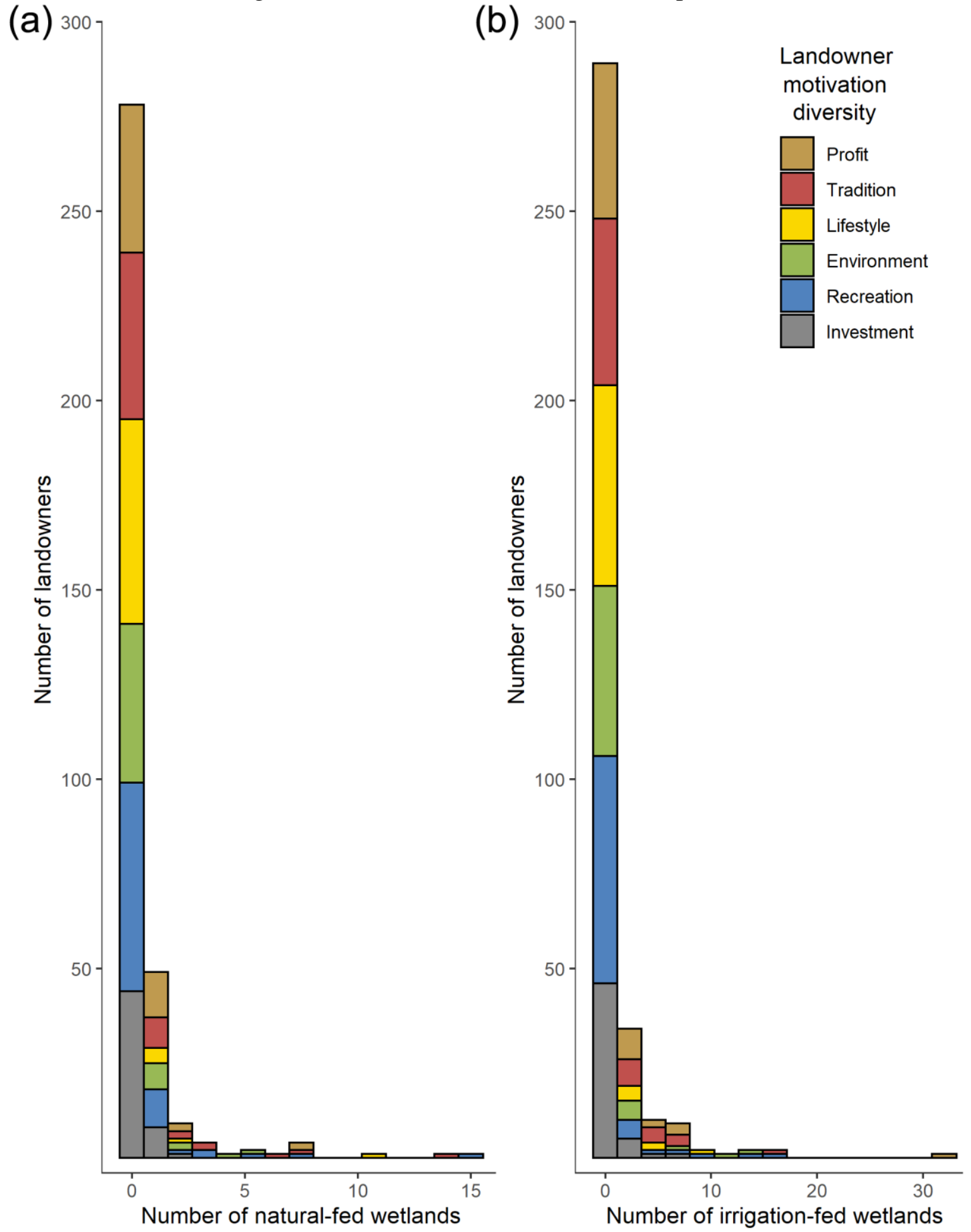